\title{
Risk Assessment in the Context of Internal Audit in Greek Listed Companies at Athens Stock Exchange*
}

\author{
Harilaos F. Harissis ${ }^{1}$, George E. Makrivogiatzakis ${ }^{2}$, Stavros E. Arvanitis ${ }^{3}$
}

\begin{abstract}
:
The objective of this paper is to highlight the strength of risk assessment within the framework of internal audit and the value could be added to modern enterprises, through its role, as a major component in modern corporate governance. Reviewing literature we concluded in applying four logistic models (logit regression), using three sets of variables for fiscal year 2010. According to our estimations, risk assessment within the framework of internal audit is positively affected by the existence of a risk management committee, the board of directors' size, the percentage of non-executive members of the board, compliance risk and environmental and security risk. These findings are partially consistent with literature. In addition, it is not affected by any other kind of risk, entity's size or subsidiaries and affiliated companies which do not match with literature. Possible explanatory factors could be either, that Greek Listed companies may be staffed with law skilled executives, or the rapid fall of the index in Athens Stock Exchange, after global recession of 2008. As far as we know there is no other research for Greek firms in risk assessment within the framework of internal audit. So, this paper contributes to research in this field.
\end{abstract}

Key Words:

Risk Assessment, Internal Audit, Non-Executive Members

JEL Classification: C83, M21, M42

\footnotetext{
* Acknowledgements: We would like to thank the anonymous referees, as well as Associate Professor of Economics Theodoros Stamatopoulos for his helpful and valuable comments.

${ }^{1}$ Member at NATO International Board of Auditors, Hellenic Court of Audit, Brussels, Belgium and Technological Educational Institute of Crete, School of Management and Economics, Department of Accounting, Greece, e-mail: charisis.charilaos@me.com

${ }^{2}$ Correspondent author: Technological Educational Institute of Crete, School of Management and Economics, Department of Accounting, Greece, e-mail: gmakrivogi@live.com

${ }^{3}$ Technological Educational Institute of Crete, Department of Accounting, Greece, e-mail: starvan@staff.teicrete.gr
} 


\section{Introduction}

Within the framework of the current intense competition, generated by globalization, a company's going concern and development is a direct function of both competitiveness and adaptability to new and increasing business risks. Risk is described as an event that could lead to business loss, including lost opportunities from actions that were omitted by entity's administration. Risk concept includes both risks that can be predicted and properly managed and those that cannot entirely be controlled (Thalassinos et al., 2010). Risk management is therefore one of the most important issues to address today's business units, because they face risks, either to a greater or a lesser extent, in the course of achieving their objectives. So, in order to manage business risks efficiently, administrations are required to have very good knowledge of the environment in which they operate (market, competition etc), excellent knowledge of business unit's functions and operations and be staffing by skilled personnel and executives, both in control and risk management (Crawford and Stein, 2002).

Particularly in recent decades, the importance of adopting proper corporate governance is highly reinforced, through a substantial business risk management and an effective and high-quality internal control system. Indeed, the introduction of a number of principles in corporate governance has required a big development in internal audit, as well, fact that plays a very important role to enhance added value to business units. Therefore, internal audit assesses and records internal procedures in practice, points out weaknesses and differences in internal control systems, provides advice, becomes a crucial factor for an effective minimization of business risks, contributes for the consolidation of corporate culture and recommends changes. Essentially, internal audit constitutes a major component in corporate governance, which protects company as also guarantee its going concern. So, it has to be adapted by modern entities, because it can work as a source of competitive advantage.

In Greece, risk management does not seem to be very well known, fact that influences internal audit's dynamics. Even the vast majority of listed companies in Athens Stock Exchange seem to be unable to understand basic principles and strategies of business risks' assessing, managing and monitoring procedures. So, there is complete lack in most listed firms not only for risk management, but also for internal audit procedures, while in family companies power is concentrated in one or a limited number of persons, who decide for business plans based on subjective rather than objective criteria (Koutoupis 2009; Thalassinos, Maditinos and Paschalidis, 2012).

Therefore, paper's purpose is to highlight the strength of risk assessment within the framework of internal audit and the value could be added to modern enterprises, 
through its role, as a major component in modern corporate governance. In order to achieve this, the effects caused on risk assessment in the context of internal control are considered, by three groups of variables, namely risk management, internal control and corporate governance, applying four logistic models (logit regression). The preparation was triggered by the fact of corporate governance's development, the rapid evolution of the process of risk assessment in the context of internal control by large groups and the relatively poor literature linking risk assessment with internal control. It is stressed that this research's object is Athens Stock Exchange listed companies, which are obliged by law to apply corporate governance's principles and internal control's procedures.

The structure of the rest of the paper is the following: second chapter discusses theoretical background, third chapter contains literature review, fourth chapter discusses materials and methods and fifth chapter presents conclusions.

\section{Theoretical Background}

\subsection{Internal audit}

Internal audit provides an extensive range of high quality services to organizations, though managers' and auditors' lack of knowledge undermining its significance that potentially could be offered. This term often is assigned by two concepts. Internal audit in the broadest sense and internal control system, which refers to organized grid functions, procedures and a comprehensive system of controls, established by administration with view to an effective functioning for business (Cheung 1997). Earlier, Meigs (1984) had specified that internal control is company's plans, methods and procedures followed by administration, in order to ensure the most efficient cooperation with management, to ensure capital, to prevent and detect fraud, to prepare accurate and complete accounting records and all relevant financial information, on time. Yet, according to Cai (1997), internal control is directly linked to the organizational structure and company's general rules and has to do not only with the administration, but also with stakeholders in regards to the correct and objective information.

Nowadays, in accordance with Standards for the Professional Practice of Internal Auditing, (2004) internal audit is an independent, objective and advisory activity, characterized by the philosophy of adding value to company's operations. It also assists organizations in achieving their objectives by following a systematic approach for evaluating and improving the effectiveness of their activities, particularly those relating to risk management, internal control systems and corporate governance. According to the definition of Internal Auditors Institute, USA (2004), the success of internal control is to identify and assess business risks, which administration intends to manage. 
Committee of Sponsoring Organizations of the Treadway Commission, (1992), depicted some of the fundamental concepts, such as that internal audit is a mean towards the achievement of operational objectives rather than objectives themselves, that is influenced by people at every level of the enterprise, that is not only policies, manuals and standards and that can only provide reasonable and not absolute assurance on management. According to General Principles of Audit, as defined by the College Chartered Accountants in Greece, accounting and administrative practice should not be completed by a single official, but the task of each must be a complementary work for, at least, one different official and be controlled by another, i.e. the internal auditor.

Internal audit's objective is the deliberate, planned and targeted impact on the existing conditions in the enterprise, which in the future could be reformed and transformed for best performance (Mcnamee and Mcnamee, 1995). On the one hand internal audit has to provide specialized and high quality services to administration, on the other hand has to provide assistance to all stakeholders, for the most effective performance of their duties with the lowest cost. One of the main concerns of internal audit is entity's compliance with rules of modern corporate governance and country's law. For this reason, is required internal control system to be reflected in specific texts, policies and procedures, regulations, circulars, Board decisions, etc.

Audit items consist of:

- Production Controls, i.e. financial audits, which include audit procedures relating to unit's assets and liabilities security.

- Operational Controls, which check the framework and compliance procedures with the entity's policies and procedures.

- Administrative Controls, which include organizational framework and procedures for obtaining administrative decisions, compliance and assessment.

Among objectives, which an entity is trying to achieve and internal audit components, that constitutes a way of achieving those specific objectives, there is a direct relationship. This relation can be represented by a three-dimensional matrix. All three categories of objectives appear in vertical columns. Five control components appear in horizontal rows. Entity's units or activities are represented by the third dimension of the matrix. Internal Audit is effective in each of those three categories of objectives, when board of directors and management take the reasonable assurance that firm's objectives are achieved, published financial statements are reliable and there is compliance with the provisions of the legislation in force. 
Figure 1: Relationship of objectives and components of internal audit

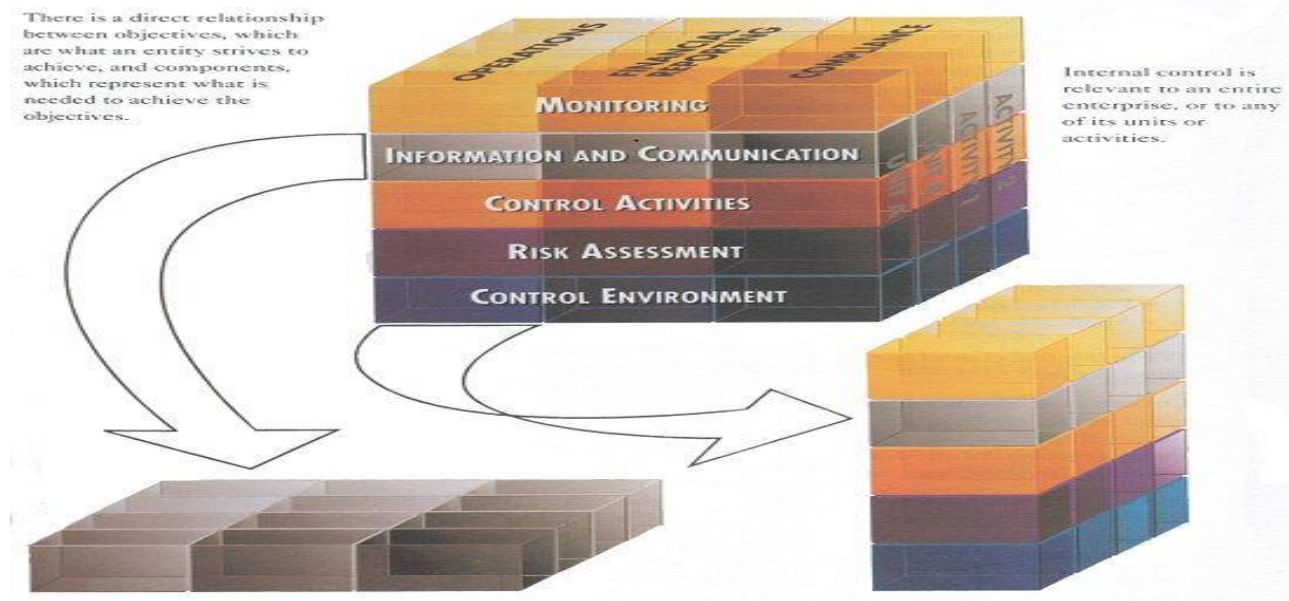

Source: C.O.S.O.

\subsection{Corporate governance - Audit committee}

Corporate governance is the cornerstone for organizing effective internal control systems in modern enterprises. The term 'corporate governance' actually describes how business units are both administered and controlled. In accordance with the principles of corporate governance of the Organization for Economic Cooperation and Development (OECD), corporate governance shall be treated as a system of relations among administration, Board of Directors, shareholders and other stakeholders.

The objective pursued by the principles of corporate governance is entity's responsible structuring, operation, management and control. Their long-term goal is to maximize business units' value and to safeguard legitimate interests of all stakeholders. In general, corporate governance's objectives are:

- To protect rights and interests for all shareholders.

- To guarantee the appropriate composition in Board of Directors, which fulfill criteria of independence and clear separation of power from administration.

- To create distinct roles in administration, which balance executives' qualifications and experience with requirements, nature and scope of business activities.

- To establish reward, assessment and development systems that can attract and retain staff with specific skills, to retain transparency, integrity and accountability in decision-making process. 
- To develop specific business processes, which illustrate everyday work and guarantee an effective internal control system that operates according to modern theories of risk management.

- To provide proper, timely and sufficient information to stakeholders, regarding entity's progress.

- To preserve social responsibility.

It is worth mentioning that an important factor in a business unit's processes of corporate governance is Audit Committee, which shall be composed with independent non-executive members of Board of Directors. Its member's role on corporate governance, risk management and internal control system in the company is:

- To ask for any information or assistance they deem appropriate, by any officer, employee or third party with whom company cooperates.

- To have access to any document, material and intangible asset, such as documents and bank accounts or any service they deem necessary for the performance of their duties.

- To assess whether administration has set the appropriate framework for internal control system, understanding the importance of risk management and internal audit at any level.

- To confirm that recommendations of internal and external audit are implemented by administration.

\subsection{Risk}

Risk refers to actions, which a business unit dares to handle and depends on the degree of freedom through a number of options (Thalassinos and Kiriazidis, 2003). This includes both risks that may be predicted and properly managed by administration, and those that cannot entirely be controlled. It is sufficient to think that risk is positively associated with performance, so risk taking degree and management capacity are two driving forces for development in the economy. According to Selim and McNamee (1998), risk includes the uncertainty that an event or some events can have a significant negative impact on achieving operational goals. Therefore, enterprise's success clearly depends on her ability to be flexible and be adjusted at changing conditions, while the appropriate risk approach should always take into account market's changes.

It is stressed though, that risk by itself does not mean anything. Therefore, when mission and objectives are set, it is necessary to take into account all possible risks. It is also said, that internal control systems in the context of risk assessment and management should be treated not only as means of containment, but as development tools, as well, namely it should be examined the nature of the impact a risk implements to the objectives of the entity. 
Risks can be classified into different categories, according to their nature or the activities they threaten, the stakeholders they affect or any possible combination.

The main risk categories are faced by modern business units are the following:

1. Business risks: They are related to the industry the company belongs and the market in which it operates.

2. Commercial or Market risks: They are risks that face traders from disorderly market developments or losses which may arise after entity's missteps in the market. In addition, it is a risk created, by the participant, in an unwanted change in the cost or performance of an asset following a change in market price. Important factor in facing commercial risks are also the adverse financial conditions in a country.

3. Credit risks: They interpret the possibility a firm not to fulfill its financial obligations. Accordingly, it means that the company may not receive its requirements.

4. Liquidity risks: They occur when there is a discrepancy in timing between assets and liabilities. They mean reduced profits, capital and assets and are expressed with the current liabilities weakness due to lack of cash.

5. Operational or Control risks: They are risks arising from inadequate internal procedures or violations of these procedures, human behavior or by external factors. They are characterized by unexpected damages which may arise from malfunctions in administration, information, support and control systems or general procedures. Sometimes, those risks results because of lack of sufficient training and education to human resources. In this field fall risks, arising from legal coverage for business issues and a wider application of law.

6. Legal risks: They are displayed in cases with non-compliance contracts or when there is insufficient supporting documentation. In general, they are related to situations that oppose the legal framework of the country in which an enterprise operates.

7. Interconnection risks: They are risks that occur between two factors that are considered to be internal in assets, securities, obligations, industries or even economies. The most common kinds are correlation risk and basis risk.

Internal control risk classification is the following:

Inherent risk: It is the probability that inaccuracies and omissions may be shown in financial statements. At this level, auditor does not take into account safeguards or existing controls, because they are directly embedded in internal control system (Taylor and Glezen, 1991, and Arens, Loebbecke, 1994). On the other hand, he uses his professional judgment and considers many factors at a view of more efficient risk assessment. Therefore, final calculation of inherent risk assessment requires 
different factors that may have either a permanent effect on the organization as a whole (Pervasive Factors) or an influence in specific accounts (Specific Inherent risk Factors). Inherent risk, in the audit risk model, is proportional to the number of evidence are controlled and inversely proportional to Detection risk.

Control risk: It is the probability that substantial inaccuracies and omissions may appear in the balance sheet, but they do not detect on time by policies and procedures of the internal control system (Gray and Manson, 2000 and Knechel, 2001). It is also the possibility that internal control system do not prevent noncompliance requirements and incorrect formulation (Filos, 2000). So, on the one hand internal auditor gathers information in accordance with audit plan. On the other hand, he determines whether the plan has been put into action or not. If he assesses risk to the ceiling, he does not need to be carried out with tests. However, if control risk is assessed below maximum score, then is required to run some. Control risk cannot be zero, because internal audits are unable to give an absolute assurance that substantial omissions and inaccuracies will be blocked and will be disclosed. At audit risk analysis model, control risk is proportional to the number of evidence are controlled and inversely proportional to Detection risk.

Detection risk: It has to do with the effectiveness of audit procedures. Unlike the other two kinds of risk, which may not be changed, this risk may be increased or reduced by internal auditor (Gill et al., 2001). Detection risk cope with the type and efficiency of procedures, the reliability of data, the procedures and the level of detail in which data are available, the number and height of accounts are examined and the implementation of the above from the auditor. There are two key points about detection risk. On the one hand, depends on all other three types of audit risk model, so it will change only if internal auditor changes one of them. On the other, specifies the number of evidence that will be collected by him. Thus, it is clear that when detection risk must be reduced, internal auditor should collect more elements to achieve reduced risk.

Consequently, audit risk model shall take the following form: $\mathrm{AR}=\mathrm{IR} * \mathrm{CR} * \mathrm{DR}$

\subsection{Risk management}

Companies are called to take a number of decisions, either more or less important, but each is connected with different kinds and levels of risk. Their common characteristic is the decision, which may be associated with stated goals or not. According to modern risk management, risks should be identified, documented and weighted according to their importance, the likelihood and the impact that may have on the enterprise, when they will be displayed. They should also be connected with registered and if possible quantified objectives (ERM COSO FRAMEWORK, 2004). Of course they can't provide an absolute cover against risk, (IIA UK, 2006). In addition, C.O.S.O. ERM (2004) introduces the concept of risk appetite, i.e. the 
extent of the risk an organization is willing to accept and risk tolerance, i.e. the acceptable level of divergence from the achievement of the objectives. According to McNamee (1998) risk management is the process of 'if and how' risk is acceptable and what actions should be taken to avoid or reduce or control.

Internal audit, in order to maintain its independence and objectivity, should not be involved in developing and implementing methodologies of risk assessment and risk management. On the contrary, it has the duty to be involved in risks' and safeguards' review, in order to guarantee that firms can achieve their goals with the most cost-effective and efficient way. In addition, internal auditors should not simply be able to assess risks, but to carry out with their analysis.

The most important advantages of an effective risk management process are the improvement of decision-making mechanisms at all entity's levels, the creation of culture for continuing improvement with the appropriate knowledge management, positive effects on performance, the fact that risks, safeguards and associated costs can be known with accuracy to administration and of course that risk management could be treated as a process rather than as a crisis manager.

Some certain elements are required, in order to be formed a suitable framework for risk assessment and risk management within the entity. Some of them could be the existence of clear written policies and procedures for risk management, risks appetite, the existence of adequate communication with company's risks and all involved employees and executives and a clear description of the role they could play in assessing and managing risks according to their hierarchical post.

It is essential that an effective risk management strategy should include risks from the top to the bottom level (top down approach) and should also take into account a cost / benefit analysis. In this particular fact, internal audit gives special attention, so as its suggestions to be linked with corresponding benefits. Additionally, in accordance with auditing standard 2100, internal auditor should help a business unit to recognize and assesses some key areas, which may pose hazards, contributing to the improvement of risk management and control systems. Besides, modern theories report that audit resources should apply to areas with the highest degree of business risk.

The fact however is that risk assessment, which is carried out either by administration for making decisions or by internal audit for setting audit plans, is largely based on assessing and rating of various risk parameters, which in total and depending on the score they receive, they determine the overall risk score. Therefore, overall risk score is essential to be published with the expression of opinion for internal control system in the annual bulletin to shareholders. 


\subsection{Risk based internal auditing}

In recent years, has developed a practice applicable to procedures of internal control, which is associated with business risks. According to this model, internal audit shall be carried out on the basis of a systematic method, which focuses on risk and not on any specific function. The main advantage of this methodology is the fact that, in a business unit, may be consumed more hours for control in high risk areas and fewer hours in areas with lower risk. So, the appropriate audit work focusing on risk is necessary to carry out the following actions:

- To take account entity's risk management strategy.

- To develop control plans on the basis of administration's risk assessment, distributing the available hours for control, properly.

- To review the strategic and annual business plan, in order to be able to assess any changes in risks and thus to adjust control plans by changing priorities, where appropriate.

- To use techniques that focus on risk management.

- To use, in audit reports, language which refers to risks rather than to individual weaknesses of safeguards.

Over the last few decades is a fact that there has been a shift for internal auditing from its traditional, in a more risk-based form. The Table 1 outlines the differences between those two methods.

Table 1: The transition from control based to risk based Internal Audit

\begin{tabular}{|c|c|c|}
\hline Characteristics & Control-based & Risk based \\
\hline Focus & Internal control systems & Business risk \\
\hline Response & $\begin{array}{l}\text { Reactive } \\
\text { Response after the event } \\
\text { Discontinuous } \\
\text { Observation of incentives in } \\
\text { strategic planning }\end{array}$ & $\begin{array}{l}\text { Proactive } \\
\text { Real-time response } \\
\text { Continuous monitoring } \\
\text { Participation in strategic planning }\end{array}$ \\
\hline Risk assessment & Risk factors & Test scenarios \\
\hline Planning & Control systems & Important risks \\
\hline Recommendations & $\begin{array}{l}\text { Internal audit: } \\
\text { Empowered } \\
\text { Cost/benefit } \\
\text { Efficient/effective }\end{array}$ & $\begin{array}{l}\text { Risk management: } \\
\text { Risk Avoiding/diversification Risk } \\
\text { Sharing/ transfer } \\
\text { Risk control/ acceptance }\end{array}$ \\
\hline Reports & Addressed to operational audits & Targeted at risks \\
\hline Role & Independent function of assessment & $\begin{array}{l}\text { Integrated risk management } \\
\text { procedure and cor. governance }\end{array}$ \\
\hline
\end{tabular}

Source: D.McNamee \& G. Selim, 1999

\section{Literature Review}

Pound (1988) and Cebenoyen et al. (1999), in their researches, according to the relationship between ownership and risk, found that depending on the type of 
shareholders and the percentage of institutional investors in an organization, the need for separation of power and risk management increases. So, they reported that as many institutional investors are, that much they want a risk-based internal audit. Pound created a sample of 100 variables, which referred to the period 1981-1985. Once he diagnosed three problems (depending on voting rights, asymmetric shocks, negative messages that old shareholders were sent to prospective shareholders), he confirmed the need for separation of power and risk management. Cebenoyen et al., studied the above link for a decade (1986-1995) and found that a rigorous legislation requires the separation of power and risk management.

In the survey conducted in 2000 in New Zealand, by Delloite \& Touche Tohmetsu for business executives and internal auditors, who replied through questionnaires and personal interviews, internal auditors mostly and executives secondary assumed that risk assessment in the context of internal audit is able to add value to a business unit. In addition, they found that risk assessment in the context of internal control has both opportunities and challenges. So, administrations who will manage challenges faster and effectively will get closer to achieve their objectives. The rest will continue to face considerable difficulties. In this research, the lack of special skills has led managers to respond negatively for the value of risk assessment in internal control.

In addition, in Sarens and De Beelde's (2006) research conducted in Belgian enterprises and Belgian subsidiaries of American firms, through interviews in 10 audit managers and collection of relevant documents, concluded that risk assessment in internal control plays different role in each country. Particularly, regarding Belgian companies, they discovered that internal auditors focus on specific risk management system's vulnerabilities, trying this way to add value in the short term. In addition, they found that internal auditors play a pioneering role in creating high level controls focusing on risks and a more standardized, transparent and documented risk management system. Regarding Belgian subsidiaries of American firms, they found that internal auditors' objective is to provide a valuable introduction, for their opinions and estimates, in the new internal audit report and appendices, required by Sarbanes Oxley law. Yet, it was found that these companies were given greater emphasis on financial audits and the quality of their reports.

Goodwin-Stewart and Kent (2006), in their research conducted in Australian public listed companies, were used a context of factors, in order to examine their characteristics linked with the existence of internal audit in relation to risk assessment and corporate governance. They found that although only one third of these companies were engaged in the operation of internal audit, however they seemed to be either supplementary or substitute with risk assessment. They also detected a strong link between the use of internal audit and risk assessment, which is 
proportional to company's size, in contrast to the weak link with corporate governance.

Knechel and Willekens (2006) in their own research on Belgian listed companies related on audit costs, risk management and internal control, found that audit costs rise, the higher the level of financial risk management is, if there is an audit committee and the more the independent members of the Board are. On the contrary, audit costs fall as compliance and control risk management increase. They also found that companies carrying out risk assessment, in their audit reports, had relatively low audit costs. These results were produced by ten risk management variables, two variants of internal audit and eight corporate governance variables.

The survey of Fraser and Henry (2007), in public companies in United Kingdom and external auditors, found that as an organization grows and complexity increases, effective risk management is becoming more difficult, but necessary. It was also found that although Audit Committee is increasingly mixed in risk management, it is expressed doubt whether their members are skilled and specialized on this specific subject. This could be very dangerous, so they propose the separation of internal audit and risk management, in order to ensure its independence and to define the role of internal audit, clearly.

Shiu and Yeh, (2008) in the survey carried out in 29 Taiwanese banks, through questionnaires and interviews with senior executives, concluded that financial risk management, compliance risk management, technological risk management, nonperforming loans ratio and the existence of a Risk Management Committee are positively associated with risk assessment in the context of internal audit. On the other hand, environmental and security risk management, control risk management and change risk management are negatively related. Additionally, regarding internal control's variables, it was found that both size and complexity have a positive relation with risk assessment in the context of internal audit. According to variables of corporate governance, there was a negative relationship among the Board of Directors' size, the number of non-executive members of the Board and risk assessment in the context of internal audit. Finally, as expected, the level of internal auditors training was found positively related on risk assessment in the context of internal audit.

In De Zwaan et al. (2008) research, was examined the effect of mixing procedures of internal audit in risk management, through a sample of 117 certified internal auditors. They found that high levels of participation in risk management block internal auditors on writing their reports with accuracy to Audit Committee, concerning followed procedures. Finally, they found that although internal auditors' involvement ensures risk management objectivity, however there are cases, which endangers this objectivity. 


\section{Materials and Methods}

\subsection{Research methodology}

This research examines risk assessment within the framework of internal audit and how is this associated with variables of risk management, internal audit and corporate governance.

Hypothesis tests are presented below for each group of variables:

RISK MANAGEMENT

$\mathrm{H}_{1}$ : Risk assessment in the context of internal audit is positively related to any kind of risk stakeholders are willing to take.

$\mathrm{H}_{2}$ : Risk assessment in the context of internal audit is positively related to the existence of a Risk Management Committee.

\section{INTERNAL AUDIT}

$\mathrm{H}_{3}$ : Risk assessment in the context of internal audit is positively related to the entity's size.

$\mathrm{H}_{4}$ : Risk assessment in the context of internal audit is positively related to the number of subsidiaries and affiliated companies.

\section{CORPORATE GOVERNANCE}

$\mathrm{H}_{5}$ : Risk assessment in the context of internal audit is positively related to the size of the Board of Directors.

$\mathrm{H}_{6}$ : Risk assessment in the context of internal audit is positively related to the percentage of non-executive members of the Board of Directors.

It also focuses on listed companies, in Athens Stock Exchange, following four logistic models (logit regression). Their annual reports have been studied, for fiscal year 2010, a year that the crisis had reached for Greek companies, in order to determine how many use risk assessment in their periodic and annual audit plans. Annual reports were drawn from the official website of Athens Stock Exchange and confirmed by listed companies' web pages.

There have also been used, three groups of variables representing risk management, internal audit and corporate governance, which have also been drawn from listed companies' annual reports. It is worth mentioning, that this survey's independent variables were based on the corresponding models of Knechel and Willekens (2006) and Shiu and Yeh (2008), who studied audit costs related to internal audit and internal control procedures that focus on risk, respectively.

The dependent variable is risk assessment in the context of internal audit (RAIA), which is set through annual reports and corporate governance statements, in chapter 
'Description of Internal Control Systems'. The independent variables are summarized in Table 2:

Table 2: Independent Variables

\begin{tabular}{|c|c|}
\hline RISK 1 & $\begin{array}{l}\text { Rating from } 1 \text { to } 5 \text {, based on the annual report and links financial risk } \\
\text { with risk management. }\end{array}$ \\
\hline RISK 2 & $\begin{array}{l}\text { Rating from } 1 \text { to } 5 \text {, based on the annual report and links compliance risk } \\
\text { with risk management. }\end{array}$ \\
\hline RISK 3 & $\begin{array}{c}\text { Rating from } 1 \text { to } 5 \text {, based on the annual report and links environmental } \\
\text { and safety risk with risk management. }\end{array}$ \\
\hline RISK 4 & $\begin{array}{l}\text { Rating from } 1 \text { to 5, based on the annual report and links technology risk } \\
\text { with risk management. }\end{array}$ \\
\hline RISK 5 & $\begin{array}{l}\text { Rating from } 1 \text { to } 5 \text {, based on the annual report and links control risk with } \\
\text { risk management. }\end{array}$ \\
\hline RISK 6 & $\begin{array}{l}\text { Rating from } 1 \text { to } 5 \text {, based on the annual report and links change } \\
\text { management risk with risk management. }\end{array}$ \\
\hline $\mathbf{R M C}$ & Dummy: 1 if there is a risk management committee and 0 if does not. \\
\hline AUDCOM & Dummy: 1 if there is an audit committee and 0 if does not. \\
\hline LNBORDNR & The natural logarithm of board members. \\
\hline NONEX & The number of non-executive members of the Board. \\
\hline NONEXP & The percentage of all non-executive members of the Board. \\
\hline IND & The number of independent non-executive members of the Board. \\
\hline INDP & The percentage of independent non-executive members of the Board. \\
\hline CEOCHR & Dummy: 1 if the CEO is also chairman of the board and 0 if not. \\
\hline LNASSET & The natural logarithm of the assets of the group. \\
\hline LNSUB & The natural logarithm of the subsidiaries and affiliates companies. \\
\hline
\end{tabular}

RISK1, RISK2, RISK3, RISK4, RISK5, RISK6 represent risk management variables, RMC, AUDCOM, LNBORDNR, NONEXP, NONEX, IND, INDP, CEOCHR represent corporate governance variables and LNASSET, LNSUB represent internal audit variables. It is noted, that this paper has used the same methods to measure risks as Knechel \& Willekens (2006) and Shiu \& Yeh (2008). Risk factors have been extracted from annual financial reports, specifically, from chapters 'Business Risks and Hazards', and 'Financial Statement's Analysis'. Each measurement resulted from the rating of 5 items for each risk factor. If risks had all 5 factors then they scored with 1 , if they had 4 out of 5 with 0.8 etc. If a risk is not completed with all five factors, then it was graded with the maximum score, i.e. whether all firms in the sample performed four elements then the best score was 4 to 4 and so on. These factors and methods of measurement are listed in the Table 3. 
International Journal of Economics \& Business Administration, I (3), 2013

H.F. Harissis - G.E. Makrivogiatzakis - S.E. Arvanitis

Table 3: Methods of Measurement

\begin{tabular}{|l|c|}
\hline \multicolumn{1}{|c|}{ Risk Factor } & Measurement \\
\hline $\begin{array}{l}\text { General information on risk exposure and } \\
\text { management practices }\end{array}$ & 1 or 0 \\
\hline Information about the risk in the current period & 1 or 0 \\
\hline Information about the risk in the previous period & 1 or 0 \\
\hline Information about the risk for future period & 1 or 0 \\
\hline Techniques for measuring risk & 1 or 0 \\
\hline Total Score & $\mathbf{0 ~ - 5}$ \\
\hline
\end{tabular}

On this basis, 4 models were tested, in order to estimate survey's hypotheses.

RAIA $_{1}=a_{1}+b_{1,0}$ RISK1 $+b_{1,1}$ RISK2 $+b_{1,2}$ RISK3 $+b_{1,3}$ RISK4 + $b_{1,4}$ RISK5 + $b_{1,5}$ RISK6 + $b_{1,7}$ RMC + $b_{1,8}$ AUDCOM + $b_{1,9}$ LNBORDNR + $b_{1,10}$ NONEX + $b_{1,11}$ NONEXP $+b_{1,12}$ IND $+b_{1,13}$ INDP $+b_{1,14}$ CEOCHR $+b_{1,15}$ LNASSET $+b_{1,16}$ SUB + $\mathrm{u}_{1}$.

RAIA $_{2}=a_{2}+b_{2,0}$ RISK1 + $b_{2,1}$ RISK2 + $b_{2,2}$ RISK3 + $b_{2,3}$ RISK4 + $b_{2,4}$ RISK5 + $b_{2,5}$ RISK6 $+\mathrm{u}_{2}$.

RAIA $_{3}=a_{3}+b_{3,0}$ RISK $3+b_{3,1}$ RISK5 $+b_{3,2}$ LNBORDNR $+b_{3,3}$ NONEXP $+u_{3}$. RAIA $_{4}=a_{4}+b_{4,0}$ RISK3 $+b_{4,1}$ RISK5 $+b_{4,2}$ RMC $+b_{4,3}$ NONEXP $+u_{4}$.

Models are applied to a sample of 235 companies listed on Athens Stock Exchange, for fiscal year 2010 (01 January until 31 December, exclusively) and are not liquidated. It is noted, that total number of listed in Athens Stock Exchange is 266, of which 25 are in suspension before 31 December 2010 and 6 more have fiscal year from 1 July to 30 June, so the final sample is made into 235 companies, namely $88,35 \%$ of total population.

With regard to survey's model analysis, the equations of multiple nonlinear regressions are performed with the logit method. In addition, each of four models was checked for heteroscedasticity, autocorrelation, variation of residues and multicollinearity. Specifically, diagnostic tests which have been carried out for hypothesis and regularity of residues is the Wald Statistic, for heteroscedasticity the Autoregressive Conditional Heteroscedasticity (ARCH) test, for autocorrelation the Akaike Information Criterion (AIC) and Bayesian Information Criterion (BIC) and for multicollinearity of variables the analysis with Spearman correlation matrix and VIF and tolerance indices.

Finally, there were used listed in Athens Stock Exchange companies, firstly because as far as we know there is no research in Greece for internal control and risk assessment in the context of internal control and secondary because information presented by listed firms are official and have reviewed from valid audit firms. 


\subsection{Descriptive statistics}

Table 4 depicts paper's basic descriptive measures. The number of observations in the sample comes to 235, while the average means of most independent variables are between 0,06 and 0,74 . It is worth mentioning that $74 \%$ of companies, in the sample, implement financial risk management, while just $29 \%$ apply with technology risk management. This fact reveals that administrations in Greek listed firms give more attention to their financial performance and risks arising from them, while they are exposed to other forms of risk that may not be measurable, but are equally important to their going concern. Furthermore, by paying attention mostly to financial risks, they are lagging behind in terms of competitiveness, with immediate effect the fall of both their stock and market value, as they come to extraordinary losses. It is also observed, that only $6 \%$ of listed companies have a Risk Management Committee, which refers mainly to banks and proves how slow Greek companies step toward risk management, fact that highlights the lack of an alternative plan in case of setbacks. It is worth noting, that $41 \%$ of listed companies have as CEO the chairman of the board, fact which evince that a large proportion of Greek listed retain their family status. It is also found that they have an average of 8 board members, 9 subsidiaries and affiliates and their average size is $150.000 .000 €$. Those numbers though did not justify, in any way, the average of the general index in Athens Stock Exchange, in 2010, which means that financial crisis in the country is not the one and only factor for its rapid fall.

Table 4: Descriptive Statistics

\begin{tabular}{|l|l|l|l|l|l|}
\hline Variable & Obs & Mean & $\begin{array}{l}\text { Std. } \\
\text { Dav }\end{array}$ & Min & Max \\
\hline raic & 235 & 0,25 & 0,43 & 0,00 & 1,00 \\
\hline risk1 & 235 & 0,74 & 0,19 & 0,40 & 1,00 \\
\hline risk2 & 235 & 0,48 & 0,17 & 0,00 & 1,00 \\
\hline risk3 & 235 & 0,42 & 0,27 & 0,00 & 1,00 \\
\hline risk4 & 235 & 0,29 & 0,27 & 0,00 & 1,00 \\
\hline risk5 & 235 & 0,40 & 0,18 & 0,00 & 1,00 \\
\hline risk6 & 235 & 0,48 & 0,24 & 0,00 & 1,00 \\
\hline rmc & 235 & 0,06 & 0,24 & 0,00 & 1,00 \\
\hline nonexp & 235 & 0,58 & 0,16 & 0,00 & 1,00 \\
\hline lnbordnr & 235 & 2,05 & 0,32 & 1,10 & 2,94 \\
\hline ceochr & 235 & 0,41 & 0,49 & 0,00 & 1,00 \\
\hline indp & 235 & 0,31 & 0,11 & 0,00 & 0,67 \\
\hline lnasset & 235 & 18,88 & 1,94 & 11,81 & 25,52 \\
\hline lnsub & 197 & 2,20 & 1,26 & 0,00 & 5,72 \\
\hline
\end{tabular}




\subsection{Test}

Correlation tests among variables in the sample are a) Spearman correlation matrix and b) VIF and tolerance test. Therefore, it does not seem to exist problems of multicollinearity among variables in survey's sample, as VIF indicator is less than 10 , with mean to 1,64 and tolerance indicator in most variables is over $50 \%$.

Furthermore, independent variables are significantly matched in all four models (percentages greater than 78\%), distribution of residues is normal and there is no matter of autocorrelation for independent variables, as AIC is too close to 1.00.

Table 5: Multicollinearity Test

\begin{tabular}{|l|l|l|l|l|}
\hline Variable & VIF & SQRT & Tolerance & R- \\
\hline raic & 1,20 & 1,1 & 0,83 & 0,17 \\
\hline risk1 & 1,32 & 1,15 & 0,76 & 0,24 \\
\hline risk2 & 1,73 & 1,32 & 0,58 & 0,42 \\
\hline risk3 & 1,70 & 1,31 & 0,59 & 0,41 \\
\hline risk4 & 1,42 & 1,19 & 0,71 & 0,29 \\
\hline risk5 & 1,55 & 1,24 & 0,65 & 0,35 \\
\hline risk6 & 1,50 & 1,22 & 0,67 & 0,33 \\
\hline rmc & 1,64 & 1,28 & 0,61 & 0,39 \\
\hline nonexp & 1,27 & 1,13 & 0,79 & 0,21 \\
\hline lnbordnr & 2,32 & 1,52 & 0,43 & 0,57 \\
\hline ceochr & 1,17 & 1,08 & 0,85 & 0,15 \\
\hline indp & 1,33 & 1,15 & 0,75 & 0,25 \\
\hline lnasset & 3,20 & 1,79 & 0,31 & 0,69 \\
\hline lnsub & 1,58 & 1,26 & 0,63 & 0,37 \\
\hline Mean VIF & $\mathbf{1 , 6 4}$ & & & \\
\hline
\end{tabular}

\subsection{Findings}

As can be seen from Table 6, models are presenting a significance level of $\mathrm{p}<0.05$, they follow normal distribution and testing variables are matching important to them. Yet, Pseudo $\mathrm{R}^{2}$ is located between $10,35 \%$ and $14,35 \%$, which means that independent variables explain significantly variations of the dependent, considering that it is testing logit models. In addition, as expected, most independent variables affect positively risk assessment in the context of internal audit, regardless statistical importance. So, there are three hypothesis tests that fully verified, one is partially verified and two are not verified at all. 
Risk Assessment in the Context of Internal Audit in Greek Listed Companies at Athens Stock Exchange

Table 6: Models

\begin{tabular}{|c|c|c|c|c|}
\hline Independent & (Model1) & (Model2) & (Model3) & (Model4) \\
\hline Variables & RAIC & RAIC & RAIC & RAIC \\
\hline \multirow[t]{2}{*}{ risk1 } & 1.456 & 1.658 & & \\
\hline & $(1.21)$ & (1.65) & & \\
\hline \multirow[t]{2}{*}{ risk2 } & 0.163 & 0.632 & & \\
\hline & $(0.11)$ & $(0.50)$ & & \\
\hline \multirow[t]{2}{*}{ risk3 } & 0.976 & 1.134 & $1.281^{\mathrm{a}}$ & $1.481^{*}$ \\
\hline & $(1.11)$ & (1.48) & $(1.90)$ & $(2.24)$ \\
\hline \multirow[t]{2}{*}{ risk4 } & 0.0167 & -0.0608 & & \\
\hline & $(0.02)$ & $(-0.10)$ & & \\
\hline \multirow[t]{2}{*}{ risk5 } & 1.901 & 1.640 & $1.951^{*}$ & $1.897^{\mathrm{a}}$ \\
\hline & (1.55) & $(1.62)$ & (1.99) & $(1.90)$ \\
\hline \multirow[t]{2}{*}{ risk6 } & 0.196 & 0.773 & & \\
\hline & $(0.21)$ & $(1.02)$ & & \\
\hline \multirow[t]{2}{*}{ rmc } & 0.585 & & & $1.098^{*}$ \\
\hline & $(0.85)$ & & & $(2.04)$ \\
\hline \multirow[t]{2}{*}{ nonexp } & $2.315^{\mathrm{a}}$ & & $2.317^{*}$ & $2.316^{*}$ \\
\hline & $(1.88)$ & & $(2.26)$ & (2.19) \\
\hline \multirow[t]{2}{*}{ Inbordnr } & 0.741 & & $0.971^{\mathrm{a}}$ & \\
\hline & $(0.91)$ & & $(1.88)$ & \\
\hline \multirow[t]{2}{*}{ ceochr } & 0.0493 & & & \\
\hline & $(0.12)$ & & & \\
\hline \multirow[t]{2}{*}{ indp } & -1.264 & & & \\
\hline & $(-0.88)$ & & & \\
\hline \multirow[t]{2}{*}{ Inasset } & -0.0599 & & & \\
\hline & $(-0.36)$ & & & \\
\hline \multirow[t]{2}{*}{ Insub } & 0.0602 & & & \\
\hline & $(0.33)$ & & & \\
\hline \multirow[t]{2}{*}{ Constant } & $-5.208^{*}$ & $-4.252^{* * * *}$ & $-5.894^{* * * *}$ & $-4.012^{* * * *}$ \\
\hline & $(-2.03)$ & $(-5.27)$ & $(-5.04)$ & $(-4.50)$ \\
\hline$N$ & 197 & 235 & 235 & 235 \\
\hline Pseudo R2 & 0.1435 & 0.1035 & 0.1182 & 0.1167 \\
\hline
\end{tabular}


International Journal of Economics \& Business Administration, I (3), 2013

\begin{tabular}{|c|c|c|c|c|}
\hline McFadden's & 0.144 & 0.104 & 0.118 & 0.117 \\
\hline $\begin{array}{l}\text { Wald } \\
\text { statistics }\end{array}$ & $\begin{array}{l}\operatorname{chi} 2(13)= \\
32.72 ;\end{array}$ & $\begin{array}{l}\operatorname{chi} 2(6)= \\
27.36 ;\end{array}$ & $\begin{array}{l}\text { chi2(4) = } \\
25.52 ;\end{array}$ & $\begin{array}{l}\operatorname{chi} 2(4)=27.20 \\
\text { Prob > chi } 2=0.000\end{array}$ \\
\hline $\begin{array}{l}\text { Hosmer \& } \\
\text { Lemeshow's } \\
\text { Goodness of } \\
\text { fit test } \\
\end{array}$ & $\begin{array}{l}\text { Pearson } \\
\text { chi2 } 2(183)= \\
205.66 ; \\
\text { Prob > }\end{array}$ & $\begin{array}{l}\text { Pearson } \\
\text { chi2 }(187)= \\
204.16 ; \\
\text { Prob > }\end{array}$ & $\begin{array}{l}\text { Pearson } \\
\text { chi2 }(148)= \\
160.05 ; \\
\text { Prob }>\end{array}$ & $\begin{array}{l}\text { Pearson } \\
\text { chi2 } 2(143)= \\
152.63 ; \\
\text { Prob }\end{array}$ \\
\hline $\begin{array}{l}\begin{array}{l}\text { Correctly } \\
\text { classified } \\
\text { (Goodness of }\end{array} \\
\end{array}$ & $79.70 \%$ & $78.72 \%$ & $81.70 \%$ & $80.00 \%$ \\
\hline$A I C$ & 1.140 & 1.070 & 1.036 & 1.038 \\
\hline$B I C$ & -770.335 & -1007.352 & -1022.159 & -1021.778 \\
\hline
\end{tabular}

The first two regression models, are not statistical significant, with the sole exception of the percentage of non-executive members, which appears to affect positively risk assessment in the context of internal audit, as reflected in first model. It is also appeared, by the second model, that financial risk affect positively risk assessment in the context of internal audit, fact that might be expected, since all listed made extensive analysis on their reports. It is mentioned though, that this conclusion is not strong enough, as probability is 1,65.

Unlike the first two models, the next two evince significant results. Particularly, third model shows positive impact to environmental and security risk management with risk assessment in the context of internal audit. Similar are the results for control risk management, the percentage of Board's non-executive members and Board's size. Regarding fourth model its differentiation in relation to the third is that instead of Board's size, positive effect on risk assessment in the context of internal audit plays the existence of a Risk Management Committee.

Specifically, in fourth regression model, the existence of a Risk Management Committee act positively in risk assessment in the context of internal audit. This result could lead in a two-way collaboration between Risk Management Committee and internal auditors, which aims to provide knowledge in risk management and internal audit executives. Of course, they could also cooperate at level of professional experience, with view to an effective and thrifty direction achieving entity's objectives.

Similarly, according to the third model, Board's size is positively associated with risk assessment in the context of internal audit. As the number of Board members expands, plurality and democracy strengthen within the Board of Directors, so risk assessment tends to be more objective and effective. In addition, companies by family type could be converted into financial institutions, because more non- 
executive and independent non-executive members within it are required. Anyway, Athens Stock Exchange must make a shift as soon as possible from small family businesses to large firms, if it wishes to put its financial role through.

Additionally, the larger the percentage of non-executive members on the Board is, the effect of risk assessment in internal audit increases even more. This result is being proved both to third and fourth regression model. It probably interprets the bad conditions in most Greek companies, confirming the moral crisis country is facing. It also stresses a need for independent and critical risk assessment from internal auditors, who must act as experts, in order to protect business units' interests. It's a fact though, that theoretically at least; non-executive members shall not act as executives, but as decision makers. So, they must be able to exercise a form of criticism or control during meetings, directly with their vote. It is believed, that a non-Executive Director must think and act based on going concern, firstly and aims at huge profits, secondly. For example, consequences could be devastating if internal audit assess that after adding a new session the existing security system has vulnerabilities and the Board does not approve upgrading for profitability's sake.

Hypothesis that risk assessment in the context of internal audit is positively related to any kind of risk stakeholders are willing to take is partially verified and only in third and fourth model, as only two of the six variables of risk management affect risk assessment in the context of internal audit.

Specifically, environmental and security risk affects positively the dependent variable in two models, fact that testifies the importance of this kind of risk and the dramatic impact that could have on entity's going concern, e.g. the imposition of a fine. As shown in table 6 , only $42 \%$ of sample's enterprises manage this specific risk. This percentage is law, given European directives and strict legislation on environmental and security issues. So, if Greek firms add this specific risk assessment in their internal audit functions, this risk could be significantly reduced, by reducing accounting provisions and extraordinary losses. Consequently they could increase their performance, indirectly.

The second risk which also affects the dependent variable of the two models is control risk. It is an indisputable fact that entity's trimming and proper structuring of internal procedures and operations is more than necessary for a smooth and uninterrupted route, especially when these are large firms or groups with complex sections or operational structure. Of course, just the existence of safeguards would not solve any problem, especially when human factor plays a significant role. It is not enough that procedures are recorded, but they must work and be reviewed regularly. Internal auditor is obliged to seek every chance they will not work at all or correctly, and this can be achieved through assessment, which must be recorded in his audit reports. It could be noted that first of all, this particular risk should be assessed by internal auditor, in order to propose later the most appropriate control 
points. It is understood that risk assessment must be carried out at regular intervals and of course whenever business unit faces changes on functions, sections etc.

On the other hand, hypotheses that risk assessment in the context of internal audit is positively related to entity's size and the number of subsidiaries and affiliated companies are not confirmed. Therefore, every modern business, regardless of size and structure is required to assess risks in the context of its internal control, in order to guarantee its going concern. Of course, the type of risk assessment, which internal audit shall carry out, depends on entity's size, structure and complexity.

\section{Conclusion}

Paper's results do not match with those of Shiu and Yeh (2008), who took a sample from 29 Malaysian banks. There are only two exceptions, namely that the existence of a Risk Management Committee is positively associated with risk assessment within the framework of internal control and the fact that it is not confirmed hypothesis that the existence of subsidiaries and affiliated companies are positively related to risk assessment in the context of internal control. Instead, results match exactly those of Knechel and Willekens (2006), who received a sample from 286 listed Belgian companies. These researchers though, found that financial risk management is statistical significant, a result which is not clearly approved by this paper.

Although there is divergence in international literature regarding risk assessment in the context of internal control, derived by lack of specialized skills from internal auditors, this paper reveals that risk assessment is an essential process for the function of internal audit, as it helps to fulfill its objective through corporate governance. Since, internal audit addresses new and ever-changing needs and expectations, its executives must broaden their knowledge and skills and must be prepared to assume a leading role in alignment of corporate strategy with risk assessment, safeguards and overall risk management processes.

In Greece, there has been made significant improvement in application of best practices for corporate governance in listed at Athens Stock Exchange companies, mainly due to the binding implementation in compliance with the relevant legal provisions, but risk management methodology remains difficult to the majority of their managers. Consequently, it's a fact that global recession of 2008 found Greek listed companies unprepared, because they had not to provide any alternative plan. Similarly, internal audit has not yet acquired the position it deserves, regardless if it is a separate function in their business charts. In any case, however, it is shown that Greek companies and executives are still not ready to integrate functions of risk assessment in internal audit. A possible cause for these situations may be the fact 
that both board members and internal audit's executives have incomplete knowledge in issues relating to risk assessment and management. On the other hand, general meetings may be satisfied staffing law skilled executives, who are fighting to increase performance or family-type companies may rely on their owners' skills. Causes and potential effects of well trained in risk assessment in internal audit executives, should be the subject for future research.

\section{References}

American Institute of Certified Public Accountants, Statement of auditing standards (SAS) no. 70 .

Atkinson, W. (2003), “Enterprise Risk Management at Wal-Mart”, Risk Management, Vol. 50, no. 12 , pp. 36-40.

Basel Committee (1999), Supervision of Financial Conglomerates, Basel Committee Publications, no. 47.

Beasley, M.S. (1996), “An Empirical Analysis of the Relation between the Board of Director Composition and Financial Statement Fraud", Accounting Review, Vol.71, pp. 443-466.

Bruce, R. (1996), "They should be: are they", Accountancy, June, p. 64.

Cadbury A, (1992), "Report of the Committee on the Financial Aspects of Corporate Governance", Gee Publishing, London.

Canadian Institute of Chartered Accountants (1995), "Report of the Canadian ICA Criteria of Control Board (CoCo)", Canada.

Carcello, J.V., D.R. Hermanson, and K. Raghunandan (2005), "Factors Associated with U.S. Public Companies' Investment in Internal Auditing", Accounting Horizons 19.2, pp. 6984.

Cebenoyan, A.S. Cooperman, E.S. and Register, C.A. (1999), “Ownership structure, charter value, and risk-taking behavior for thrifts", Financial Management 28 (1), pp. 43-60.

Chambers, Chambers, A.D (2000), "Internal audit and risk management: impact on internal audit - development or revolution?", Internal Control 32, pp. 3-7.

Chen, H.J. (2003), "The Relationship between Corporate Governance And Risk-Taking Behavior in Taiwanese Banking Industry", Journal of Risk Management 5 (3), pp. 363 391.

Colbert, J.L., Alderman, C. W. (1995), "A risk driven approach to the Internal Audit", Managerial Auditing Journal, Vol. 10, no. 2, pp. 38-44.

Committee of Sponsoring Organizations of the Treadway Commission (COSO Report) (1992), Internal Control, Integrated Framework, USA.

Cooper, B.J., Leung, P. and Mathews, C. (1994), "Internal audit: an Australian profile", Managerial Auditing Journal, 9, pp. 13-19.

COSO Committee (2004), Enterprise Risk Management Framework, USA.

De Zwaan, L., (2009), Internal audit involvement in Enterprise Risk Management, Discussion Papers, Accounting, Griffith Business School.

Deloitte and Touche Tohmatsu (2000), Achieving Internal Audit Excellence, Deloitte and Touche Tohmatsu, Wellington.

Fama E and Jensen M (1983), "Separation of Ownership and Control", Journal of Law and Economics, Vol. 26, pp. 301-325. 
Filos, I. (2001), "Internal Regulation of Operations”, Logistis Journal, June, pp. 935-936.

Fraser, I., and W. Henry (2007), "Embedding risk management: structures and approaches", Managerial Auditing Journal 22 (4) pp. 392 - 409.

Gibbs, J. and Keating, P. (1995), "Reengineering Controls", Internal Auditor Vol. 52, Iss. 5, October, pp. 46-49.

Goodwin, J. (2003), "The Relationship between the Audit Committee and the Internal Audit Function", Evidence from Australia and New Zealand, International Journal of Auditing, 7, pp. 263-278.

Goodwin, J. and P. Kent (2006), "The use of internal audit by Australian companies", Managerial Auditing Journal, Vol. 21, No. 1, pp. 81-101.

Griffiths, D.M. (2006), Risk Based Internal Auditing- An Introduction.

Griffiths, P. (1999), "Understanding the expectations of finance directors towards internal audit and its future", Managerial Auditing Journal, Vol. 14 No. 9, pp. 487-8.

Haniffa, R., and M. Hudaib, (2006), "Corporate Governance Structure and Performance of Malaysian Listed Companies", Journal of Business Finance \& Accounting 33 (7-8) pp.1034-1062.

Hubbard, L.D. (2000), “Audit planning”, Internal Auditor, Vol. 57, No. 4, pp. 20-21.

Hubbard, L.D. (1988), "Control Self Assessment Facilitating Techniques Workbook", The Institute of Internal Auditors, June.

Jensen, M., and J. Warner (1988), "The distribution of power among corporate managers, shareholders, and directors", Journal of Financial Economics, 20, pp. 3-24.

Leung, P., Cooper, B.J. and Robertson, P. (2003), The role of internal audit in corporate governance, The Institute of Internal Auditors Research Foundation, RMIT University, Australia.

Maijoor, S. (2000), “The internal control explosion”, International Journal of Auditing, Vol. 4, pp. 101-9.

Marcella, Albert J. Jr (1995), “Outsourcing, Downsizing, and Reengineering: Internal Control Implications”, Altamonte Springs, FL: The Institute of Internal Auditors.

Morgan, G. (1979), "Internal audit role conflict: a pluralist view", Managerial Finance, Vol. 5 No. 2, pp. 160-70.

Myers, P.M. and Gramling, A.A. (1997), "The perceived benefits of certified internal auditor designation", Managerial Auditing Journal, 12, pp. 70-79

Pentland, B. (2000), "Will auditors take over the world? Program, technique and the verification of everything, Accounting", Organizations and Society, Vol. 25, pp. 307-12.

Pound, J. (1988), "Proxy Contests and the Efficiency of Shareholder Oversight", Journal of Financial Economics, January/March, pp. 237-265.

Ross, S.A. (1989), "Institutional Markets, Financial Markets, and Financial Innovation", Journal of Finance, July, pp. 541-556.

Sarens, G. and De Beelde, I., (2006), "Internal auditors' perception about their role in risk management. A comparison between US and Belgian companies", Managerial Auditing Journal, Vol. 21, no. 1, pp. 63-80.

Selim G. and McNamee (1999), "Risk Management and Internal Auditing: What are the Essential Building Blocks for a Successful Paradigm Change?", International Journal of Auditing, Vol.3, pp. 147-155.

Selim G. and McNamee (1999), "The Risk Management and Internal Auditing Relationship: Developing and Validating a Model", International Journal of Auditing, 3, pp. 159-174. 
Shiu, Y.M. and Yeh, M.L. (2008), Risk Based Internal Auditing in Taiwanese Banking Industry.

Spira, L.F. and M. Page (2003), "Risk management: The reinvention of internal control and the changing role of Internal Audit", Accounting, Auditing \& Accountability Journal, Vol. 16, No. 4, pp. 640-61.

Thalassinos I.E., Maditinos D. and Paschalidis A. (2012), "Observing Evidence of Insider Trading in the Athens Stock Exchange (ASE)", Journal of Economic Structures, 1:8, 52 67, 03 Dec., available at: www.journalofeconomicstructures.com/content/1/1/8.

Thalassinos, I.E. and Kiriazidis, T. (2003), "Degrees of Integration in International Portfolio Diversification: Effective Systemic Risk", European Research Studies Journal, Vol. VI(1-2), pp. 111-122.

Thalassinos, I.E., Deceanu, L., Pintea, M. and Zampeta, V. (2010), "New Dimensions of Country Risk in the Context of the Current Crisis: A Case Study for Romania and Greece", European Research Studies Journal, Vol. XIII(3), pp. 225-236.

The Institute of Internal Auditors Risk Based Internal Auditing, UK and Ireland.

Ye Liu (2004), Control Self Assessment Combined with SOX, Cass Business School. 